\title{
A New Interpretation of Geodynamic Context and Typology of Moroccan Anti-Atlas Silver Deposits
}

\author{
Wafik Amina, Professor \\ Ramdani Abderahmane, Geologist \\ El Aouad Nouaman, PhD student \\ El Ghazali Mohamed, Geologist
}

Faculté des Sciences Semlalia/ Université Cadi Ayyad,

Département de Géologie, DLGR, URAC 43, Marrakech, Morocco

doi: 10.19044/esj.2017.v13n12p424 URL:http://dx.doi.org/10.19044/esj.2017.v13n12p424

\begin{abstract}
The argentiferous deposits in the Anti-Atlasic chain in Morocco are encased in the meta-sedimentary, volcanic-sedimentary and volcanic terrains of the Neoproterozoic, structured and schistosed during the Pan-African orogenesis. These deposits are associated with terminal Neoproterozoic rhyolites and granitoids. The deposits of Zgounder, Imiter and Bou Madine have similarities; Structurally are controlled and associated with faults; The source of the mineralization is generally magmatic or crustal. Precipitation of the mineralization would result from the mixing of mineralized fluids with meteoric waters or brine pools. The silver deposits in the Anti-Atlas are characterized by a number of criteria, which confirm their orogenic character. These deposits are associated with orogenic accretion events in relation to Pan-African orogenesis during the Neoproterozoic. Mineralization is syn- to post-peak metamorphism, controlled and associated faults, with veins that can have significant vertical extensions. The pressure gradients, and temperature metamorphism, indicating an orogenic environment, with metamorphic facies greenschist in general. These deposits can all be linked to an argentiferous mega-event during the Upper Neoproterozoic and thus define an argentiferous metallogenic province.
\end{abstract}

Keywords: Silver, orogenic, mineralization, Anti-Atlas, Morocco

\section{Introduction}

The Anti-Atlas is a large metallic province encircled in Precambrian terrains, which flush out in the form of buttonholes. Most of these buttonholes contain mineralizations that are in development or in development, including the silver mineralization of Imiter, Zgounder, 
Polymetallic from Bou Madine and Bou Azzer. These deposits have been the subject of numerous studies for several decades. This paper constitutes the first synthesis on the contingency between argentiferous mineralization and the geodynamic context in the Moroccan Anti-Atlas. The present objective is to identify, the orogenic characteristics in the argentiferous deposits in the Anti-Atlas in the south of Morocco, the relations between these argentiferous deposits and the geodynamic context. Three main deposits are studied in this work, each with a different buttonhole, the Bou-Madine polymetallic deposit (Ougnat buttonhole). The Imiter Ag-Hg deposit (Imiter "J.Saghro" buttonhole) and the Zgounder Ag-Hg deposit (Siroua Massif); With a small glimpse of the Bou Azzer deposit. Mineralization is considered in its macroscopic aspect, as it can be observed in the field and microscopic as it is observed under the microscope. In identifying the mineralized structure, there are two major obstacles : the age of much of the mineralization, multistage mineralization; - the absence of a rigorous nomenclature, respected by the various researchers. A summary that fits well with the concern of this article has been drawn, with slight adaptations. It is now necessary to interpret the relationship between the mineralization of a number of argentiferous sites and their geodynamic environment. Such an interpretation necessarily involves the more or less complex chain of processes that gave rise to mineralization. This sequence can spread out over time, or even require one or more mineralizing phases. It is therefore impossible to observe the succession and / or the combination of the elementary processes which lead to an argentiferous mineralization. There will thus always remain a part of hypothesis linked more particularly to certain processes for which, however, a certain consensus is gradually.

Silver is a precious metal, which exists in nature in the native state, of sulphides and sulphosalt. In the Anti-Atlas silver is presented in the form of silver parageneses, Ag-Hg amalgam, silver sulphide and sulfosalts, (argentite or acanthite (Ag2S), silveropyrite (AgFe2S3), schapbachite (AgBiS2), aguilarite (Ag4SeS) and canfieldite (Ag8SnS6), polybasite (Ag, Cu) $16 \mathrm{Sb} 2 \mathrm{~S} 11$, etc.), They are often associated with base metal sulphides and sulfosalts such as arsenopyrite, pyrite, galena, sphalerite and chalcopyrite. Among the elementary processes, there are many geologic or geomorphological processes which are perfectly defined: alteration, dissolution, and transport with precipitation.

\section{Classifications of deposits in general:}

A popular classification proposed by Lindgren (1933) distinguishes the deposits formed in the different levels of the crust. The term "epithermal", "mesothermal", and "catathermal" are still used today to describe shallow deposits, intermediate depths, and deposits formed at depth. At the end of 
the 20th century, the development of the theory of plate tectonics spread a whole series of classifications related to the tectonic context, Arndt \& Ganino (2010). Deposits in ocean basins were distinguished from those in convergent zones or those in intracratonic contexts. This category of classification is still used, particularly when discussing the global distribution of deposits. However, these types of classifications have now largely been replaced by other types of classifications where the basic criterion is the process responsible for mineralization (Table 3). Arndt \& Ganino (2010).

\section{Characteristics of orogenic deposits}

Several studies have been made on orogenic deposits, especially orogenic gold. They show a number of common characteristics for this type of deposit Kerrich et al (2000).

\section{Geological, geodynamic and metallogenic context of Anti-Atlas}

The Anti-Atlas (Figure 1) represents the northern end of the COA, extending over $700 \mathrm{~km}$ in a WSW-ENE direction. The anti-atlasic chain is subdivided into three domains: 1) the western part extending from the Atlantic to the foot of the Jbel Siroua. 2). The central part which includes the Jbel Siroua and the region of Bou Azzer, El Graara. 3) The eastern part includes the Jbels Saghro and Ougnat. The Major Anti-Atlas WNW-ESE accident limiting the Western Anti-Atlas of the Central and Eastern AntiAtlas (Choubert, 1947 ; in Tuduri, 2005).

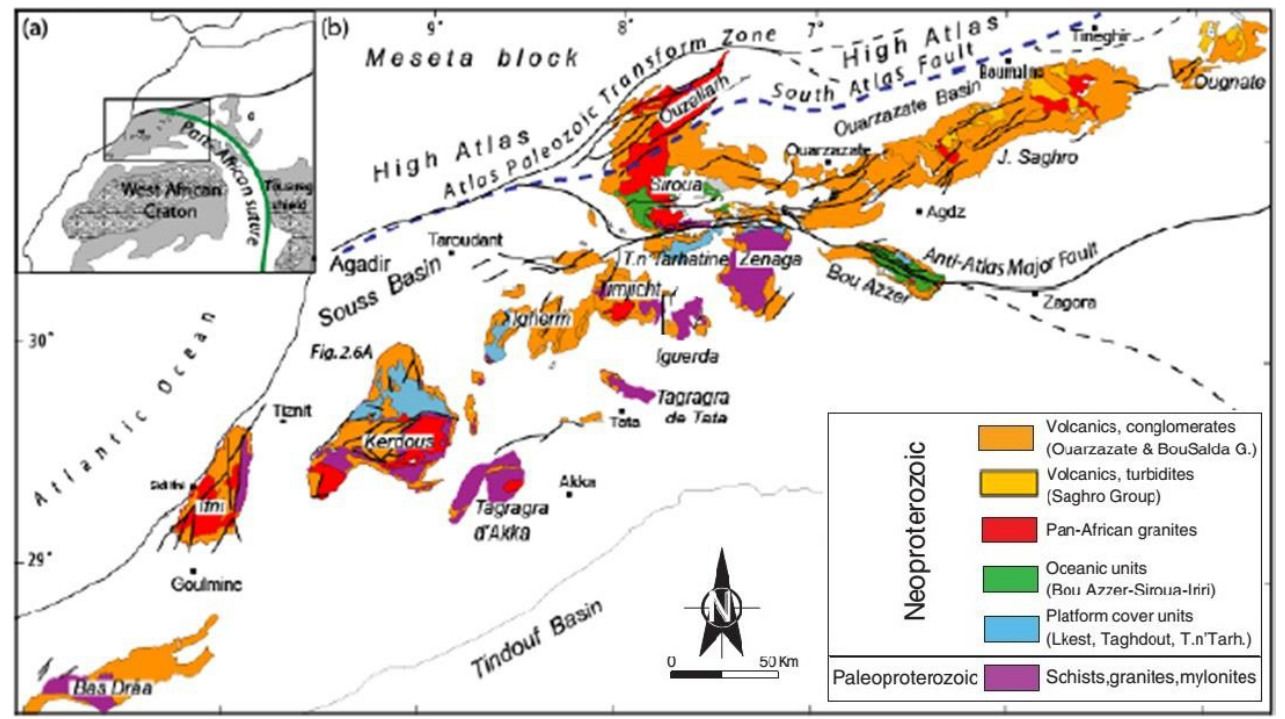

Figure 1. The schematic map of the Precambrian boutonnieres of the Anti-Atlas and the localization sketch at the top left (Wafik et al, 2015). 
In summary (Table 1), the Precambrian terrains of the Anti Atlas are formed by two distinct groups: 1) An ancient substratum of Paleoproterozoic age, structured during the Eburnian orogenesis (Tuduri, 2005). 2) Neoproterozoic lands linked to the pan-African cycle (Gasquet et al, 2008).

\begin{tabular}{|c|c|c|c|}
\hline \multicolumn{2}{|c|}{ Age } & Groups & Lithology \\
\hline Paleozoic & Adoudounien & Taroudant Group & Dolomie, conglomerate \\
\hline \multirow{5}{*}{ 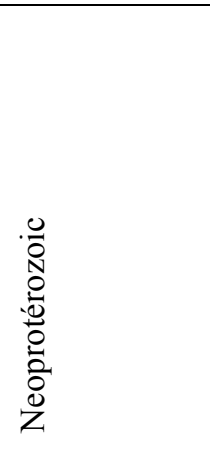 } & \multirow{3}{*}{ 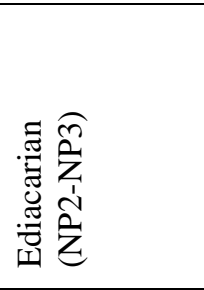 } & $\begin{array}{l}\text { Ouarzazate Group (NP3) } \\
(580-550 \mathrm{Ma})\end{array}$ & Rhyolite, granite, conglomerate \\
\hline & & $\begin{array}{l}\text { Bou Salda Group (NP2-3) } \\
(610-580 \mathrm{Ma})\end{array}$ & $\begin{array}{l}\text { Sediment no classified, Volcanism } \\
\text { and plutonism of potassium and } \\
\text { calcium-alkaline. }\end{array}$ \\
\hline & & $\begin{array}{l}\text { Saghro Groupe } \\
(630-610 \mathrm{Ma})\end{array}$ & $\begin{array}{l}\text { Turbidites, tholeitic potassic and } \\
\text { calco-alcaline magmatism,. }\end{array}$ \\
\hline & Cryogenian & $\begin{array}{l}\text { Bou Azzer-Iriri Group } \\
(760-700 \mathrm{Ma})\end{array}$ & $\begin{array}{l}\text { Bou Azzer Ophiolite. Iriri } \\
\text { Tonalite, gneiss, rhyolite, andésite }\end{array}$ \\
\hline & $\begin{array}{l}\text { Tonian } \\
\text { (NP2) }\end{array}$ & $\begin{array}{l}\text { Lkest-Taghdout Group } \\
\text { (1000-880Ma) }\end{array}$ & $\begin{array}{ll}\text { Conglomerate, } & \text { limestones, } \\
\text { Quartzite and dolerite } & \end{array}$ \\
\hline $\begin{array}{r}\text { Paleo } \\
\text { proterozoic }\end{array}$ & $\begin{array}{l}\text { Eburnean } \\
\text { (PI) }\end{array}$ & $\begin{array}{l}\text { Zenaga-Kerdous Group } \\
(2.2 \mathrm{Ga}-2 \mathrm{Ga})\end{array}$ & $\begin{array}{l}\text { Schists, granites, mylonites, } \\
\text { paragneiss, dolerite veins... }\end{array}$ \\
\hline
\end{tabular}

Table. 1. Summary of the generalized lithostratigraphic column for the pan-African orogen of the Anti-Atlas after Thomas et al. (2004), modified by Gasquet et al. (2005) \& Liégeois et al. (2006).

The main events are the development of a neoproterozoic "Rifted margin" divergence margin, oblique subduction, the formation of the "insular" intraoceanic arc, continental arc collision and the eventual development of an active continental arc The north margin of the COA.

The result of Hefferan et al (2014), by the combination of numerous works (Thomas et al., 2002, 2004 ; Gasquet et al., 2008 ; Abati et al., 2010 ; El Hadi et al., 2010 ; Walsh et al., 2012 et autres), Is the identification of the distinct orogenic events of the Pan-African cycle (Figure.2) :

a). Rifting of Rodinia which consequently the development of the passive margin of the COA and the sea floor 885-760 Ma. The evidences of the operation of this rifting are manifested by diabase dykes which cross the base Eburnéen in the buttonhole of Zenaga. Oceanization corresponds to the ophiolites of Siroua and Bou Azzer-El Graara. The deposits of the passive margin are recorded in the group of Lkest-Taghdout (Thomas et al, 2004. ; Alvaro et al 2014 ; in Hefferan et al, 2014).

b) The subduction to the north of the oceanic lithosphere under the island arc of Iriri and formation of the oasolite of Tasriwine in the buttonhole of Siroua and the ophiolite Bou Azzer / the insular arc of TazigzaoutTichibanine in the buttonhole of Bou Azzer -El Graara 760-700 Ma.

This subduction is proved by several data including the dating of Metagabbro de Tazigzaout by Lemos et al., (2006), 752 + 1 / -3 Ma and the 
dating of the Granite d'Oumlil in the Bou Azzer- El Graara697 \pm 8 Ma by El Hadi et al. (2010).

c) Subduction to the north of $675 \mathrm{Ma}$. In the Saghro buttonhole, dated synorogenic intrusions confirm this subduction; The Tonalite d'Igoudrane (Schiavo et al, 2007) and granodiorite of Tiboulkhirine (Massironie et al, 2007 in Hefferan et al, 2014). La collision de l'arc insulaire d'Iriri Siroua,l'arc insulaire de Tazigzaout-Tichibanine et le complexe ophiolitiquede Bou Azzer 680-640 Ma avec le COA. The consequence of this collision is the development of a metamorphism of green schist type to amphibolite or even probably schist blue (Hefferan et al. 2014).

d) Beginning of the subduction which plunges southward under the COA with development of the potassic magmatism of continental arc. Magmatism was then followed by the development of the clastic basin (620-570 Ma) and collision 615-555 Ma.

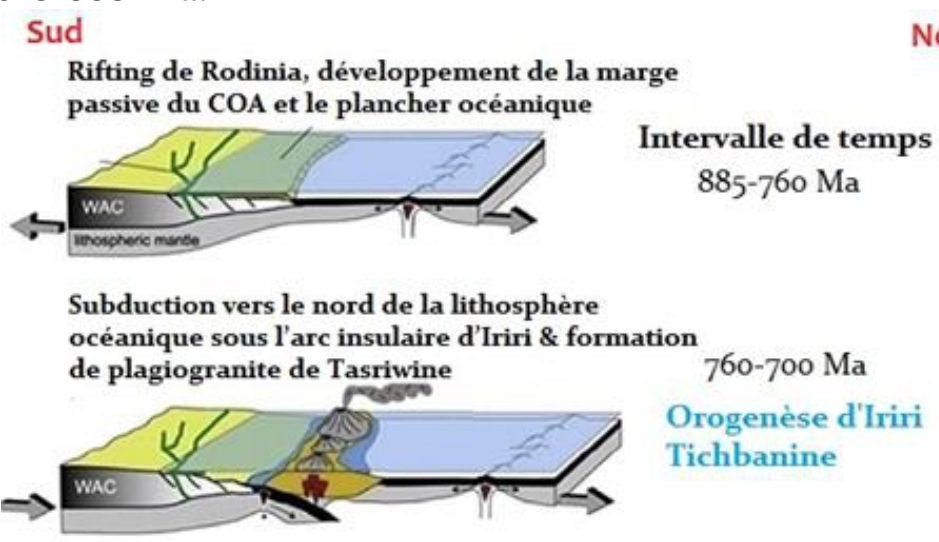

Collision de l'arc insulaire d'Iriri avec le COA \& Obduction d'Ophiolite. Intrusion de diorite 680-640 Ma quartzique \& métamorphisme

Nord

Rifting de Rodinia, développement de la marge

Intervalle de temps

$85-760 \mathrm{Ma}$

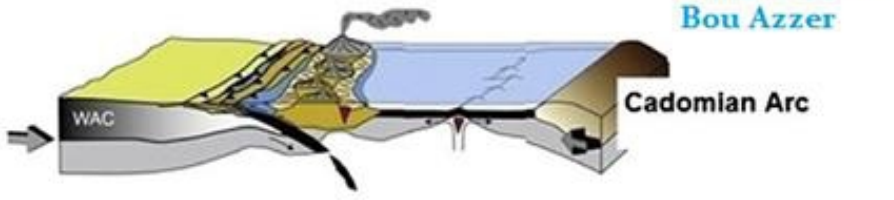

Subduction vers le sud sous le COA, convergence avec l'arc cadomien, suivi par le développement du bassin clastique

620-555 Ma

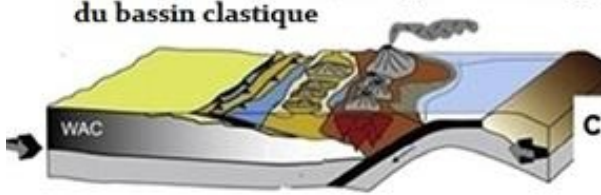

Orogenèse COA-

Cadomia

Cadomian Arc

Figure.2. Schematic model showing the Proterozoic tectonic evolution of the Anti-Atlas. Developed by Saquaque et al. (1989), Hefferan et al. (1992, 2000), Thomas et al. (2002, 2004), Gasquet et al. (2005, 2008), Abati et al. (2010), El Hadi et al. (2010) and Walsh et al. (2012), modified by Hefferan et al, (2014). 
The post-Panafrican sedimentary series of the Anti-Atlas (Figure 4) begins with deposits of the terminal Neoproterozoic, followed by the Palaeozoic sediments from the Cambrian to the Upper Carboniferous. The complete sequence is about 8-9 km thick in the western Anti-Atlas, whereas it is about 4-5 km in the eastern Anti-Atlas, south of the Saghro and Ougnat. In general, in the Anti-Atlas the sedimentary series were deposited in shallow marine environments (Michard et al, 2008).

\section{Metallogenic Context of the Anti-Atlas}

The Moroccan Anti-Atlas is a vast metallic province (Figure 3) which contains numerous deposits and indices with base or precious metals known for more than a millennium (Tuduri, 2005, ). One can conclude from the substances exploited and / or enclosed in most of these deposits, that the Anti-Atlas is a metallic argentiferous province.

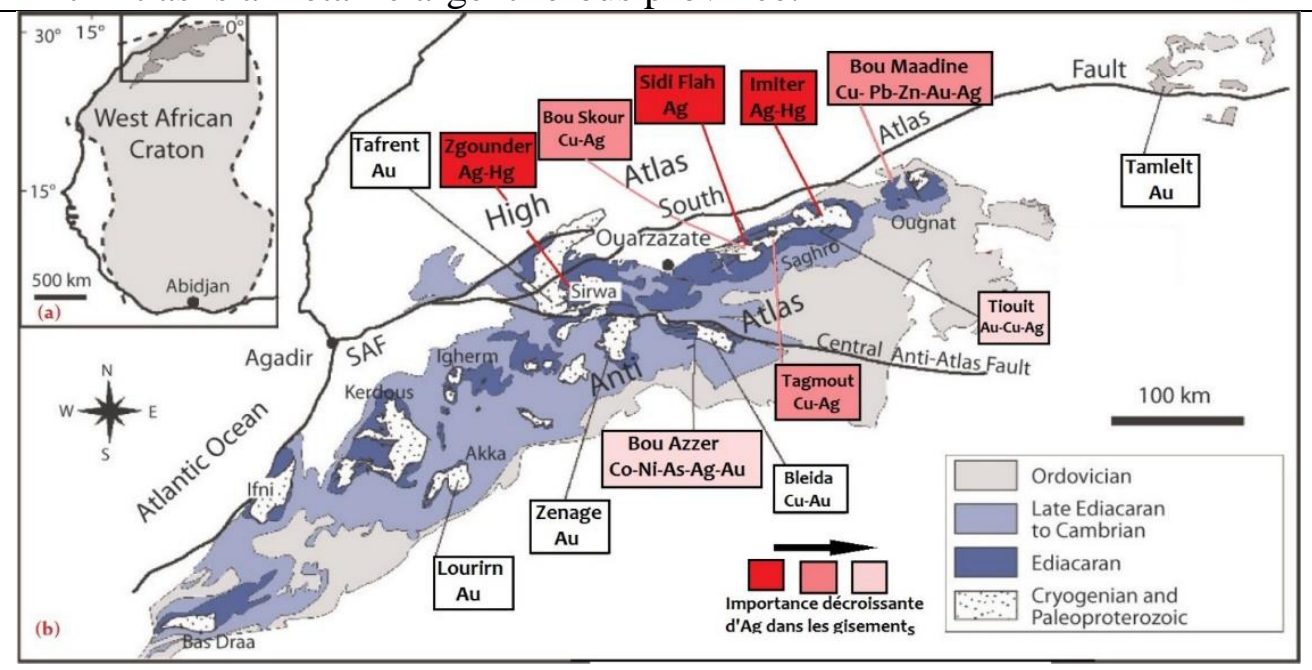

Figure. 3.(a) The Anti-Atlas orogenic belt at the northern limit of the COA. (B) a schematic geological map of the anti-atlas chain and the location of the main mineral deposits,

(Gasquet, 2005). Completed.

\section{The silver deposits in the Anti-Atlas}

\section{The polymetallic deposit of Bou-Madine (Massif de l'Ougnat, Anti-Atlas oriental)}

The Bou Madine deposit is located in the Precambrian boutonniere of the Ougnat at the eastern end of the Anti-Atlas range, about $200 \mathrm{~km}$ as the crow flies north of Ouarzazate (Figure 4, 5 ). The Precambrian buttonhole of the Jbel Ougnat (Figure 8) located in the Eastern Anti-Atlas is composed of two large lithostructural units which are: 
1- The pleated metasedimentary base (Fig. 5 \& 6), schistosed, of "middle" Neoproterozoic age (Saghro Group) composed of pelites and turbiditic grauwackes intersected by granitoid, Levresse, (2001). They develop a contact metamorphism with biotite, cordierite, andalusite and garnet in the metasedimentary series (Levresse, 2001).

2- The volcanoclastic coverage of the terminal Neoproterozoic ("NP3") rests unconformably on the metasedimentary base directly or through gaps with elements of the base (Paile, 1983 ; Freton,1988 ; Ait Saadi, 1992, in Levresse, 2001).

Three stages of mineralization controlled by structural evolution are distinguished by Abia \& Soulaimani, (2011), these stages have been divided into sub-stages or episodes, based on textures (Figure.7). The main characteristics of Bou Madine silver deposit are summarized in the table 2:

\begin{tabular}{|c|c|}
\hline Minéralisation host & $\begin{array}{l}\text { The volcaniclastic coverage of the terminal } \\
\text { Neoproterozoic; Formation (FTT) with } \\
\text { ignimbrites, andesitic casting and rhyolitic } \\
\text { intrusions }\end{array}$ \\
\hline $\begin{array}{l}\text { Age of igneous rocks associated } \\
\text { with mineralization }\end{array}$ & 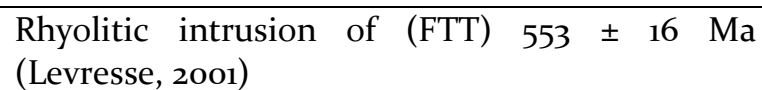 \\
\hline Morphology and textures of ore & Filling of veins; massive, banded et breacciated ore \\
\hline $\begin{array}{l}\text { Mineralization stages } \\
\text { (Abia et al, 2003 \& Abia \& } \\
\text { Soulaimani, 2011). }\end{array}$ & $\begin{array}{l}\text { Stage I : Fe-As- (Sn) stage : } \\
\text { - Episode (1a): massive or banded pyrite } 1 \\
\text { (pyrrhotite and cassiterite). } \\
\text { - Episode } 1 \mathrm{~b}: \text { arsenopyrite (arsenopyrite 1) } \\
\text { Stage II : (Zn-Pb-Fe-Cu-Sn): } \\
\text { - Episode (2a) with sphalerite and accessory } \\
\text { chalcopyrite, pyrite and stannite, and } \\
\text { - Episode (2b) galena. } \\
\text { Stage III : (As-Fe-Pb-Zn-Cu-Ag-Sb-Bi) with } \\
\text { arsenopyrite, pyrite, traces of galena, sphalerite, } \\
\text { chalcopyrite, gray copper, argentopyrite (AgFe2S3), } \\
\text { schapbachite (AgBiS2), aguilarite (Ag4SeS) \& } \\
\text { canfieldite (Ag8SnS6) }\end{array}$ \\
\hline Conditions of ore formation & $\begin{array}{l}\text { Temperature between } 360^{\circ} \mathrm{C} \text { et } 150^{\circ} \mathrm{C} \text {. } \\
f S \text { entre } 10^{-18 \cdot 8} \text { bar et } 10^{-9 \cdot 7} \text { bar. } \\
\text { The minimum fluid trapping temperature } \\
\text { between } 150^{\circ} \mathrm{C} \text { and } 200{ }^{\circ} \mathrm{C} \text { for estimated } \\
\text { trapping pressures of } 400 \text { bar. } \\
\text { the fluid's } \mathrm{pH} \text { for temperatures of } 150^{\circ} \mathrm{C} \text { to } 300^{\circ} \mathrm{C} \text {, } \\
\text { respectively between } 6.5 \text { et } 7 .\end{array}$ \\
\hline Source of mineralization & $\begin{array}{l}\text { Crustal (Abia et al (1999). } \\
\text { Magmatic (Levresse, 2001) } \\
\text { Mixing with meteoric waters or brines from the } \\
\text { Adoudounian Basin (Levresse et al., 2004). }\end{array}$ \\
\hline Age of Mineralization & Contemporary with rhyolitic intrusions of (FTT) \\
\hline
\end{tabular}




\begin{tabular}{|c|c|}
\hline & $553 \pm 16 \mathrm{Ma}$ (Levresse, 2001) \\
\hline Genetic model & $\begin{array}{l}\text { - A copper porphyry, With an ESE-WNW extension } \\
\text { regime at the origin of the normal faults of direction } \\
\mathrm{N} 70^{\circ} \mathrm{E} \text { to } \mathrm{N} 30^{\circ} \text { related to rhyolitic intrusion age } \\
553 \pm 16 \mathrm{Ma} \text {, (Levresse, 2001). } \\
\text { - A neutral epithermal type (low-sulfidation or even } \\
\text { sericite-adular), controlled by the NW-SE and NE- } \\
\mathrm{SW} \text { during the late panafrican phase. Sub- } \\
\text { contemporary to the placement of rhyolitic domes } \\
\text { dated by Levresse (2001) à } 553 \pm 16 \text { Ma (Abia \& } \\
\text { Soulaimani, 2011). }\end{array}$ \\
\hline Orogenic characteristic identified & $\begin{array}{l}\text { - The Bou Madine deposit is associated with } \\
\text { neoproterozoic orogenic accretion events. } \\
\text { - Mineralization is syn-to post-peak of } \\
\text { metamorphism, controlled and associated with faults, } \\
\text { with veins that may have significant vertical } \\
\text { extensions. } \\
\text { - Presence of metamorphic Green schist facies. } \\
\text { Pression, temperature and metamorphism gradients } \\
\text { indicate orogenic environment. } \\
\text { - The ore is associated to acide alteration (quartz- } \\
\text { sericite-pyrite) durant the stage (a1). }\end{array}$ \\
\hline
\end{tabular}

Table 2 : Main characteristic of Bou Madine silver deposit. 


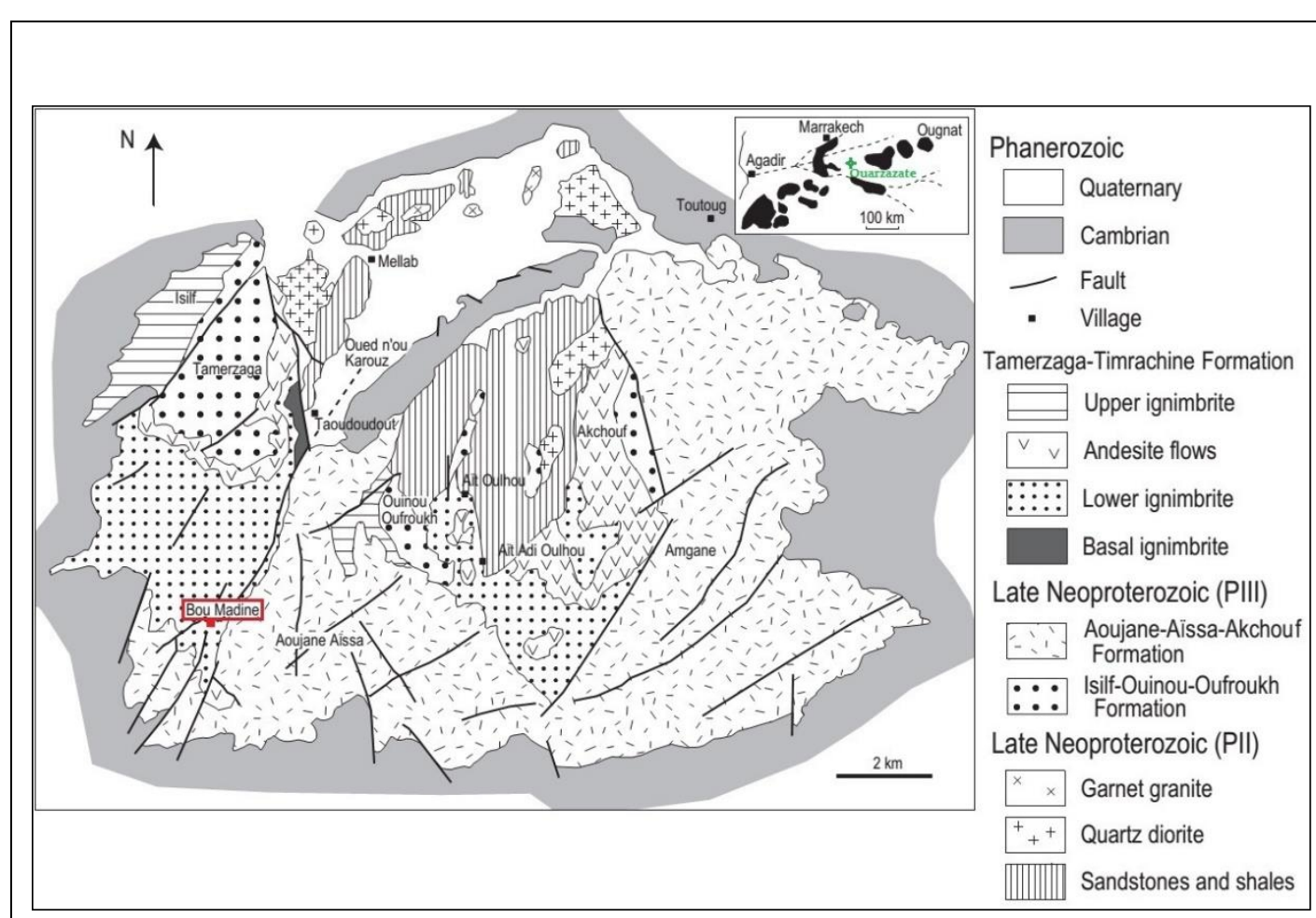

Figure.4. Simplified geological map of the Ougnate buttonhole, with location of Bou Madine deposit. (Abia et al, 2003) completed

Figure. 5. Lithostratigraphic column of Bou Madine (Paile, 1983 ; in Levresse, 2001), completed

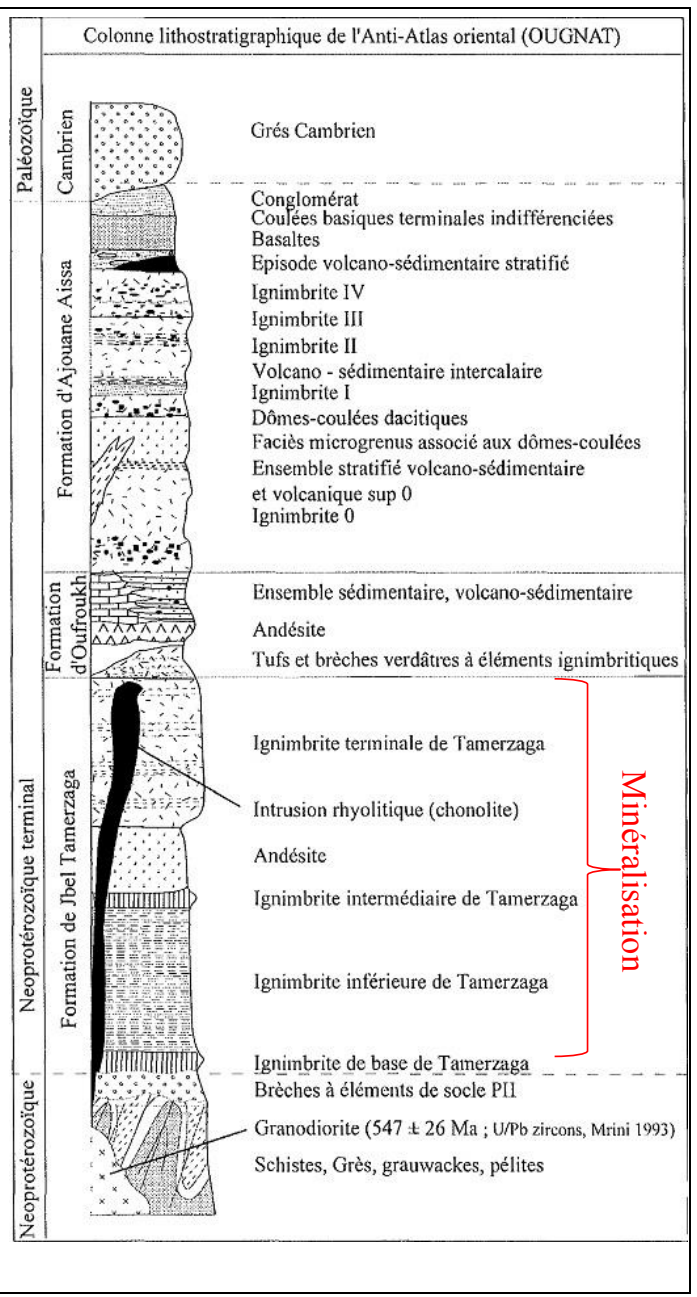




\section{Imiter Silver deposit (Saghro Massif, oriental Anti-Atlas)}

Imiter district is located in the north of Imiter bouttonhole (at GPS coordinates : N 31 $\left.21^{\prime} 4.47^{\prime \prime}, \mathrm{W}^{\circ} 43^{\prime} 39.27^{\prime \prime}\right)$. The Imiter silver deposit is distributed along the Imiter fault (Figure 6), oriented $\mathrm{N} 70^{\circ} \mathrm{E}$ to $\mathrm{N} 90^{\circ} \mathrm{E}$. hosted by the meta-sedimentary lands of the middle Neoproterozoic "Saghro Group" accompanied by a penetrative schistosity (Ouguir et al., 1994; Maacha et al., 2015; Lebdev et al. 2016) and at the base of volcanosedimentary and volcanic formations of the Upper Neoproterozoic "Ouarzazate group" (Maacha et al, 2015). These terranes were structured during the Pan-African orogeny by a folding of the E-W axis to ENE-WSW. The whole is covered in major discordance by the sedimentary formations carbonate, and pelitic and sandy of the middle Cambrian (Maacha et al, 2015). Three types of orientation bodies $\mathrm{EW}$ to $\mathrm{N} 70^{\circ} \mathrm{E}$ (Gaouzi et al, 2011 ; Maacha et al, 2015; Lebdev et al., 2016; ). The main ore characteristic are summarized in table 3 . 

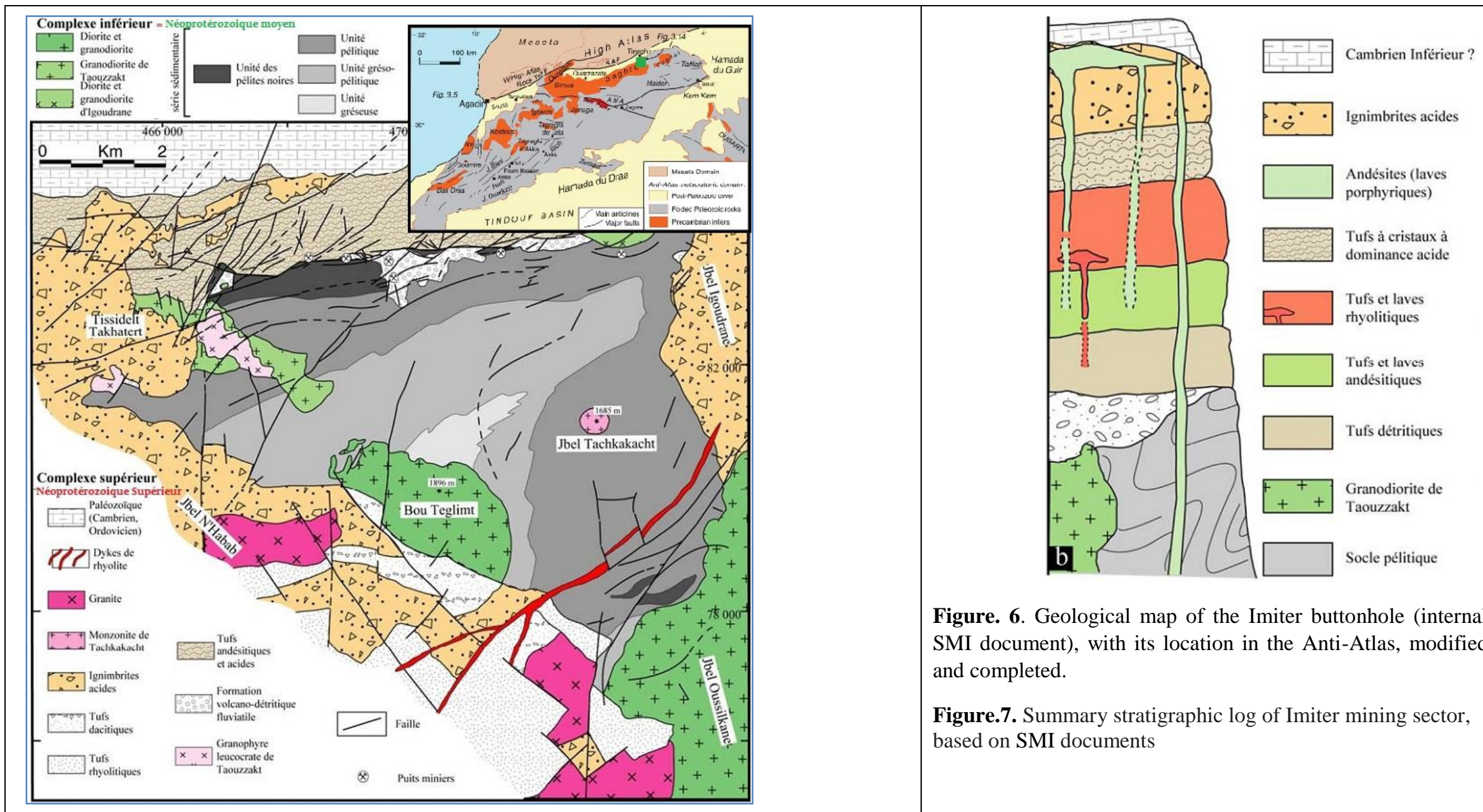

Figure. 6. Geological map of the Imiter buttonhole (internal SMI document), with its location in the Anti-Atlas, modified and completed.

Figure.7. Summary stratigraphic log of Imiter mining sector, based on SMI documents 


\begin{tabular}{|c|c|}
\hline Ore-bearing rocks & $\begin{array}{l}\text { The ore is distributed along the fault bundle, encased in the mid- } \\
\text { Neoproterozoic meta-sedimentary terrains and at the base of volcanic- } \\
\text { sedimentary and volcanic formations of the Upper Neoproterozoic } \\
\text { (Maacha et al.,2015; Lebdev et al. 2016) }\end{array}$ \\
\hline $\begin{array}{l}\text { Age of igneous rocks } \\
\text { associated } \\
\text { mineralization }\end{array}$ & $\begin{array}{l}\text { Taouzzakt Granodiorite } 572 \pm 5 \mathrm{Ma} \text { and Takhatert rhyolite } 550 \pm 3 \mathrm{Ma} \text {, } \\
\text { (Levresse, 2001) }\end{array}$ \\
\hline $\begin{array}{l}\text { Ore morphology and } \\
\text { textures }\end{array}$ & $\begin{array}{c}\text { Clusters, veins; massive ore, ribbon, breccia, disseminated or in } \\
\text { stockwerk... }\end{array}$ \\
\hline Mineralization stages & $\begin{array}{l}\text { - The first syngenetic and tectono-metamorphic stage, (Fe) pyrite and } \\
\text { milky quartz veins in black shales (associated panafrican metamorphism } \\
\text { foliation) (Levresse, 2001). } \\
\text { - The early hydrothermal sulphide stage : The silver epithermal stage } \\
(\mathrm{Pb}, \mathrm{Zn}, \mathrm{Cu}, \mathrm{Fe}, \mathrm{As}, \mathrm{As}-\mathrm{Co}-\mathrm{Ni}, \mathrm{Hg} \text { and } \mathrm{Ag} \text { ) (pyrite, arsenopyrite, } \\
\text { chalcopyrite, galena, copper-gray, sphalerite silver amalgam, silver } \\
\text { sulfosalts, and argentite) and imiterite) (Guillou et al. 1985) associated } \\
\text { with E-W quartz veins (Qtz2 phase)) and N130 }{ }^{\circ} \mathrm{E} \text { dolomite veins } \\
\text { breccias (dolomite phase) with sometimes hydraulic. Spatially they are } \\
\text { related to the granitoids and the aureole of contact metamorphism } \\
\text { (Levresse, 2001). }\end{array}$ \\
\hline $\begin{array}{l}\text { Ore's formation } \\
\text { Conditions }\end{array}$ & $\begin{array}{l}\text { Temperature between } 350^{\circ} \mathrm{C} \text { et } 180^{\circ} \mathrm{C} \\
\text { Pressions between } 0,8 \text { à } 5 \mathrm{kbar} \text {, during tectono-metamorphic stage. } \\
\text { Aqueous magmatic fluids with } \mathrm{pH} \sim 7 \text {; and salinity } \sim(0,5 \text { to } 14,5 \text { eq. } \\
\mathrm{NaCl} \text { ). } \\
\mathrm{Ag} \text { is carried in the solution in the form of sulphide complexes }(\mathrm{Ag}(\mathrm{SH}) \text { - } \\
\left.{ }^{2}\right) \text {. Precipitation of metals is probably related to the mixing of deep fluids } \\
\quad \text { and superficial fluids (brine) (Levresse, 2001). }\end{array}$ \\
\hline Ore Source & $\begin{array}{l}\text { The sulphides associated with argentiferic paragenesis would have a } \\
\text { purely mantle source }(90 \%) \text { to be related to felsic volcanism. The } S \text { of the } \\
\text { pyrites comes from the black shales and the late-neoproterozoic felsic } \\
\text { volcanism, (Levresse et al., 2004). }\end{array}$ \\
\hline Ore deposit Age & $\begin{array}{l}\text { Neoproterozoic terminal; Contemporary to the introduction of } \\
\text { Takhatert572 } \pm 5 \mathrm{Ma} \text { rhyolite intrusions and Taouzzakt550 } \pm 3 \mathrm{Ma} \\
\text { granodiorite (Levresse, 2001). }\end{array}$ \\
\hline Genetic model & $\begin{array}{l}\text { - Succession of tectono-metamorphic, magmatic and volcanic episodes of } \\
\text { reconcentrations of a syngenetic metal stock closely associated with black } \\
\text { shales. (Baroudi et al. (1999), } \\
\text { - An epithermal model related to rhyolitic magmatism at the end of the } \\
\text { terminal Neoproterozoic (Levresse, 2001). In these two cases, the authors } \\
\text { agree that a distensive tectonic characteristic of the Precambrian-Cambrian } \\
\text { transition would favor the formation of structural traps (Tuduri, 2005). }\end{array}$ \\
\hline $\begin{array}{l}\text { Orogenic characteristics } \\
\text { identified }\end{array}$ & $\begin{array}{l}\text { The ore in the Imiter deposit is hosted by meta-sedimentary sequence } \\
\text { deformed and schistosed syn at post-peak panafrican metamorphism. The } \\
\text { ore is distributed along the fault bundle of significant vertical extensions, } \\
\text { linked to the major accidents "fault of Imiter". The pressure, temperature } \\
\text { and metamorphism gradients, indicating an orogenic environment. }\end{array}$ \\
\hline
\end{tabular}

Table 3 : Main characteristic of Imiter silver deposits 


\section{Zgounder silver ore deposit (Siroua Massive, Central Anti-Atlas)}

The Zgounder silver deposit is located on the western flank of the Precambrian massif of Siroua in the Anti-Alas, about $200 \mathrm{~km}$ east of Taroudant (Figure 4) .GPS: N $30^{\circ} 45^{\prime} 44$ ", W $07^{\circ} 44^{\prime} 35$ "; Alt. 2000 m. The Siroua massif belongs to the pan-African orogenic domain, it is located north of the Major accident of the Anti-Atlas (Figure.1 \& 3).

In the Siroua massif the terrain consists of a volcanosedimentary series, the Zgounder series assigned to the terminal Neoproterozoic by Choubert \& Faure Muret (1990). It is bordered on the west by a terminal Neoproterozoic granodiorite massif, covered to the east by volcano-detritic formations, of the Neoproterozoic terminal and by phonolites And Neogene Tuffites (Marcoux \&Wadjinny, 2005 ; Essarraj \& Michard, 2011).

This series of Zgounder is straightened, shows an E-W direction (Fig. 8) and a strong dip towards the south; It would correspond to the southern flank of an anticline E-W direction (Essarraj \& Michard, 2011). It occupies an area of about $9 \mathrm{~km} 2$, formed by three series, one distinguishes from the base to the top (in Marcoux \&Wadjinny, 2005):

- The blue series, is thick 300 and $400 \mathrm{~m}$, composed of sandstones, grauwackes and pelites, with levels of tuff, the whole being capped by a level of orange rhyolite;

- The brown series, also 300 to $400 \mathrm{~m}$ high, consisting of micaceous and sandy schists, and breccias and pelites with fragments of volcanic glasses. This formation is capped by a dolerite sill;

- The black series at the summit, about 900 in thickness, composed of an acidic volcanic complex (ignimbrites, rhyolitic breccias), which forms the roof of mineralized levels. To the south, this formation ends with sandstones and grauwackes, with intermediate levels of conglomerate (Figure 8).

- Two types of metamorphism appear in the series bearing mineralization at Zgounder, A regional epizonal and the second contact. The latter is caused either by the intrusion of the Askaoun granite, located to the west of the terminal neoproterozoic mine (575 $\pm 8 \mathrm{Ma}$, U-Pb zircon, Thomas et al., 2002), and by Associated rhyolitic intrusions (Figure 8 ), or by a dolerite sill. A Neogene volcanism "Pontian" materialized by trachytic tuffs and phonolites is observed further east, J. Siroua volcano (Essarraj \& Michard, 2011).

- The Zgounder area is affected by four fractures: east-west, northsouth, "sub-vertical" and two conjugate systems, NE-SW and NWSE. They can be interpreted as fractures associated with the E-W folding of the series (Marcoux \& Wadjinny, 2005; Essarraj \& Michard, 2011). 
In the Zgounder deposit, silver mineralization is located at the top of the brown (schisto-sandstone) formation, encased in pelitic levels, tuffaceous breccias and dolerite. The silver mineralization can be observed up to $70 \mathrm{~m}$ inside the shale, with a higher concentration in the first 20 to $25 \mathrm{~m}$. The mineralization is closely associated with the E-W grinding zones and the N-S fracture zones (Smeykal, 1972; Petruk, 1975) (Figure.9). The mineralization takes the form of a lens of variable dimensions (10 to $25 \mathrm{~m}$ wide and 20 to $60 \mathrm{~m} \mathrm{long}$ ), but follow the east-west fractures with a general dip to the south. The rooting of these fractures, recognized up to $300 \mathrm{~m}$, is disturbed by subhorizontal faults (Marcoux \& Wadjinny, 2005).

The main characteristic of Zgounder silver mineralization are summarized in the table 4. 


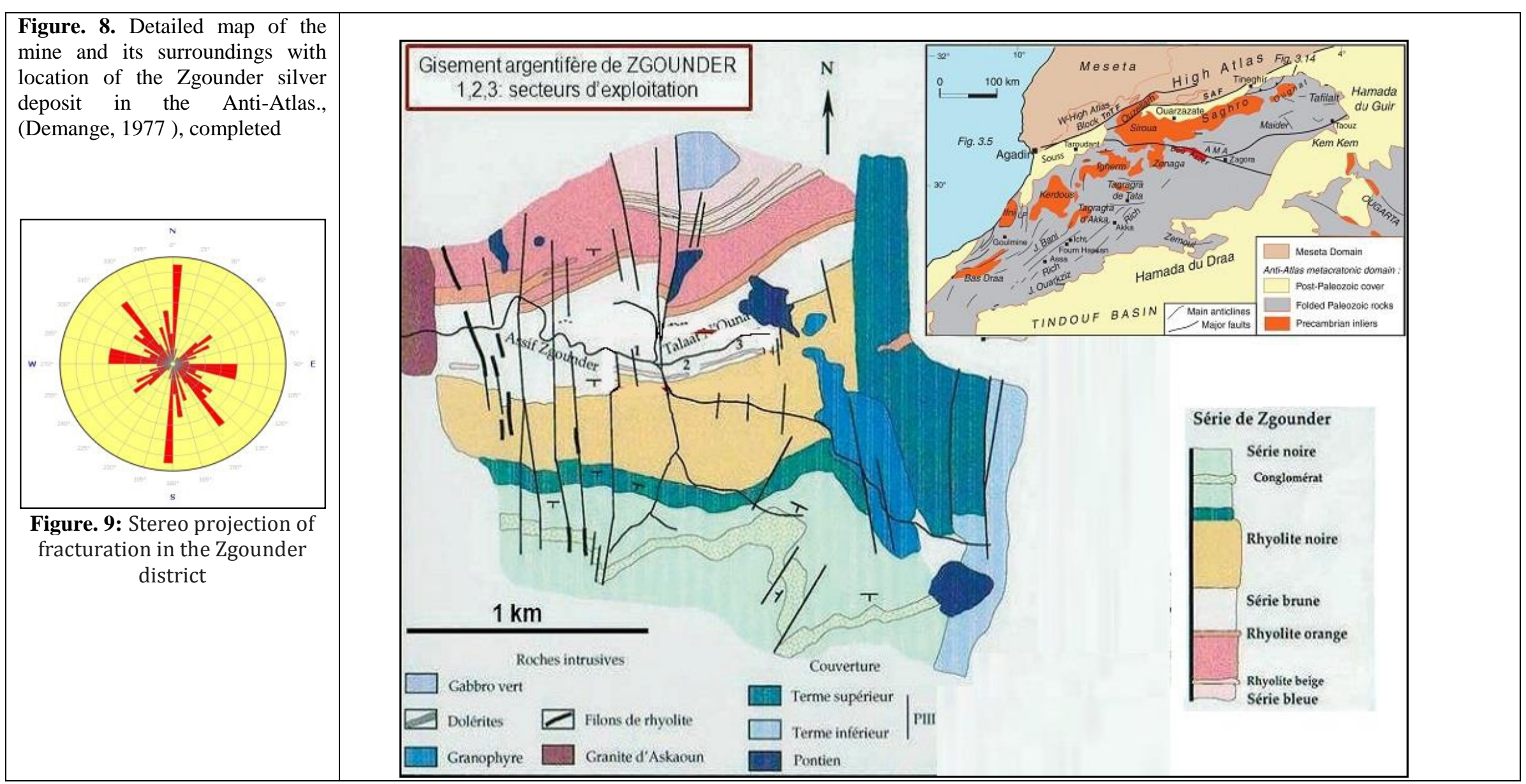




\begin{tabular}{|c|c|}
\hline Ore-bearing rocks & $\begin{array}{l}\text { In the Zgounder deposit, argentiferous mineralization occurs at the top of } \\
\text { the brown (schisto-sandstone) formation, encased in the volcano- } \\
\text { sedimentary series, pelitic levels, tuffaceous breccias and dolerite. }\end{array}$ \\
\hline $\begin{array}{l}\text { Age of igneous rocks } \\
\text { associated } \quad \text { with } \\
\text { mineralization }\end{array}$ & $\begin{array}{l}\text { The intrusion of the Askaoun granite, located to the west of the terminal } \\
\text { neoproterozoic mine ( } 575 \pm 8 \mathrm{Ma} \text {; U-Pb zircon, Thomas et al., 2002). } \\
\text { End-Neoproterozoic Rhyolites }\end{array}$ \\
\hline $\begin{array}{l}\text { Morphology and } \\
\text { textures of ore }\end{array}$ & $\begin{array}{l}\text { Lenses of variable dimensions ( } 10 \text { to } 25 \mathrm{~m} \text { wide and } 20 \text { to } 60 \mathrm{~m} \text { long), } \\
\text { Clusters, veins; Solid ore, ribbon, breccia, disseminated or in stockwerk }\end{array}$ \\
\hline Mineralization stages & $\begin{array}{l}\text { The early stage(E) (Fe-As- } \mathrm{Ag}): \text { pyrite-arsenopyrite with nanoinclusions } \\
\text { of } \mathrm{Ag}(20 \mu \mathrm{m}) \text { in } \mathrm{E}-\mathrm{W} \text { veinlets and brecciated zones. } \\
\text { The polymetallic late stage (Cu-Pb-Zn-Ag-Hg) : chalcopyrite-galena } \\
\text { sphalerite, native } \mathrm{Ag} \text {, } \mathrm{Ag}-\mathrm{Hg} \text { amalgam (predominant argentiferous } \\
\text { phases), acanthite, galena, pearceite, polybasite and } \mathrm{Ag}-\mathrm{Hg} \text { sulphide } \\
\text { paragenesis in } \mathrm{N}-\mathrm{S} \text { quartz-albite-chlorite or siderite-calcite veins,: } \\
\text { (Essarraj \&Michard, 2011). Two populations of silver were pointed out } \\
\text { Marcoux \& Wadjinny, (2005) a reveal slightly later remobilisations. }\end{array}$ \\
\hline $\begin{array}{l}\text { Ore formation } \\
\text { conditions }\end{array}$ & $\begin{array}{l}\text { The aqueous fluids responsible for mineralization are trapped at high } \\
\text { temperatures }\left(450-3000^{\circ} \mathrm{C}\right) \text { at widely varying pressures }(0.5-1.9 \mathrm{kbar}) \\
\text { during the early stage. } \\
\text { For the late stage, the temperature conditions are about } 200^{\circ} \mathrm{C} \text {., and the } \\
\text { fluids are of the hypersaline brine type, under pressures, } \mathrm{P}<1 \mathrm{kbar} \text {. }\end{array}$ \\
\hline $\begin{array}{l}\text { Source } \\
\text { mineralization }\end{array}$ & $\begin{array}{l}\text { The continental crust, without the perceptible participation of the mantle } \\
\text { (Marcoux \& Wadjinny, 2005). }\end{array}$ \\
\hline Age of mineralization & $\begin{array}{l}\text { The analysis of the isotopic composition of galena lead makes it possible } \\
\text { to calculate a terminal Neoproterozoic age for mineralization about } 510 \\
\text { Ma (Marcoux \& Wadjinny, 2005) }\end{array}$ \\
\hline Genetic model & $\begin{array}{l}\text { Deposits in veinlets and brecciated zones of generally E-W direction (early } \\
\text { high temperature stage, sulphides and sulfo-arsenides of FeAs-Co) are } \\
\text { generally related to late-Pan-African evolution (Essarraj \& Michard, } \\
\text { 2011). } \\
\text { hydrothermal circulations are of magmatic and / or metamorphic origin } \\
\text { For, in corridors of compressive deformation in magmatic arc context } \\
\text { (relative to Askaoun pluton ( } 575 \pm 8 \mathrm{Ma} \text {,) (Smeykal ;1972; Popov, 1989), } \\
\text { The late stage epithermal silver and base metal, lower temperature and } \\
\text { pressure conditions corresponds to exhumation of the Pan African } \\
\text { (Essarraj et al., 1998; in Essarraj \&Michard, 2011) or post-orogenic } \\
\text { extension during the Upper Ediacaran-Lower Cambrian 510 Ma, By } \\
\text { mixing with very saline surface brines (Marcoux \& Wadjinny, 2005) }\end{array}$ \\
\hline $\begin{array}{l}\text { Orogenic } \\
\text { characteristic } \\
\text { identified }\end{array}$ & $\begin{array}{l}\text { It is encased in structured and schistosed meta-sedimentary lands during } \\
\text { the Pan-African orogeny, with an epizonal regional metamorphism. The } \\
\text { ore is distributed along the fault bundle of significant vertical extensions, }\end{array}$ \\
\hline
\end{tabular}




\begin{tabular}{|l|l|}
\hline & $\begin{array}{l}\text { the rooting of these fractures, recognized up to } 300 \mathrm{~m} . \\
\text { gradients }(0.5-1.9 \mathrm{kbar}), \text { Temperature }\left(450-1800^{\circ} \mathrm{C}\right) \text { and metamorphism, } \\
\text { indicating an orogenic environment. Syn to post-peak metamorphism, } \\
\text { during the formation phase of the pan-African orogenic belt. }\end{array}$ \\
\hline
\end{tabular}

Table 4 : Main characteristic of Zgounder silver deposits

\section{Genetic relationships between silver deposits in the Anti-Atlas}

The Anti-Atlas is an silver metallic province characterized by a set of deposits that can be genetically linked. In the table below (table 5) we will make a correlation between the deposits studied.

\begin{tabular}{|c|c|c|c|}
\hline Ore deposit & Bou Madine & Imiter & Zgounder \\
\hline $\begin{array}{l}\text { Ore-bearing } \\
\text { rocks }\end{array}$ & $\begin{array}{l}\text { volcanoclastic coverage } \\
\text { of (NP3). }\end{array}$ & $\begin{array}{l}\text { meta-sedimentary serie of the } \\
\text { middle (NP2) and at the base of } \\
\text { the volcanic-sedimentary and } \\
\text { volcanic formations of (NP3). }\end{array}$ & $\begin{array}{l}\text { volcano-sedimentary } \\
\text { series, pelitic levels, } \\
\text { tuffaceous breccias and } \\
\text { dolerite, (NP3) }\end{array}$ \\
\hline $\begin{array}{l}\text { Age of igneous } \\
\text { rocks associated } \\
\text { with } \\
\text { mineralization }\end{array}$ & $\begin{array}{l}\text { Rhyolitic Intrusion of } \\
\text { (FTT) } 553 \pm 16 \mathrm{Ma} \\
\text { (Levresse, 2001) }\end{array}$ & $\begin{array}{l}\text { Taouzzakt Granodiorite } 572 \pm 5 \\
\text { Ma \& Takhatert rhyolite } 550 \pm 3 \\
\text { Ma, Levresse, }(2001)\end{array}$ & $\begin{array}{l}\text { Askaoun granodiorite } \\
\text { intrusion, (575 } \pm 8 \quad \mathrm{Ma}) \\
\text { (Thomas et al., 2002). \& } \\
\text { rhyolite }\end{array}$ \\
\hline $\begin{array}{l}\text { Ore Morphology } \\
\text { and textures }\end{array}$ & $\begin{array}{l}\text { Fills veins; massive ore, } \\
\text { banded and brecciated }\end{array}$ & $\begin{array}{l}\text { Clusters, veins; or in stockwerk } \\
\text { Massive ore, ribbon, breccia, } \\
\text { disseminated... }\end{array}$ & $\begin{array}{l}\text { Lenses, clusters, veins, } \\
\text { stockwerk massive ore, } \\
\text { breccia, disseminated or } \\
\text { in }\end{array}$ \\
\hline $\begin{array}{l}\text { Ore formation } \\
\text { conditions }\end{array}$ & $\begin{array}{l}\text { The temperature } \\
\text { between } 360 \circ \mathrm{C} \text { and } \\
150^{\circ} \mathrm{C} \text {. } \\
\text { The pressure } \sim 0.4 \mathrm{Kbar} \text {. } \\
\text { The pH : } 6.5-7 \text {. } \\
\text { fluid salinity of } 1 \% \text { eq. } \\
\mathrm{NaCl}\end{array}$ & $\begin{array}{l}\text { The temperature between } 350^{\circ} \mathrm{C} \\
\text { and } 180^{\circ} \mathrm{C} \text {. } \\
\text { The pressures of } 0.8 \text { to } 5 \mathrm{kbar} \text {, } \\
\mathrm{pH}: \sim 7 . \\
\text { fluids are aqueous with salinity of } \\
(0.5-14.5 \text { eq. } \mathrm{NaCl}) \text {. }\end{array}$ & $\begin{array}{l}\text { temperature } 200-4500^{\circ} \mathrm{C} \text {. } \\
\text { pressures largely variable } \\
0.5-1.9 \text { kbar } \\
\text { hypersaline brine type }\end{array}$ \\
\hline $\begin{array}{l}\text { Source of } \\
\text { mineralization }\end{array}$ & $\begin{array}{l}\text { Magmatic source for } \\
\text { (Levresse, 2001) } \\
\text { Crustal source, (Abia et } \\
\text { al (1999). }\end{array}$ & $\begin{array}{l}\text { Purely mantle magmatic source } \\
(90 \%) \text {. } \\
\text { The S of pyrites comes from black } \\
\text { shales and felsic volcanism }\end{array}$ & $\begin{array}{l}\text { Continental crust, without } \\
\text { the perceptible } \\
\text { participation of the } \\
\text { mantle (Marcoux \& } \\
\text { Wadjinny, 2005). }\end{array}$ \\
\hline $\begin{array}{l}\text { Age of } \\
\text { mineralization }\end{array}$ & $\begin{array}{l}\text { Contemporary at the } \\
\text { introduction of the } \\
\text { rhyolite intrusion of } \\
\text { (FTT) } 553 \pm 16 \mathrm{Ma} \\
\text { (levresse, 2001) }\end{array}$ & $\begin{array}{c}\text { Contemporary to the introduction } \\
\text { of Takhatert } 572 \pm 5 \mathrm{Ma} \text { rhyolite } \\
\text { intrusions and Taouzzakt } \\
\text { granodiorite } 550 \pm 3 \mathrm{Ma} \\
\text { (Levresse, } 2001 \text { ). }\end{array}$ & $\begin{array}{lr}\text { The age of the } \\
\text { mineralization about } & 510 \\
\text { Ma (Marcoux } & \text { \& } \\
\text { Wadjinny, 2005) }\end{array}$ \\
\hline
\end{tabular}

Table 5 : comparative table between the Bou Madine, Imiter and Zgounder silver deposits.

\section{The relationship between the Zgounder and Imiter deposits}

Zgounder and Imiter deposits have strong analogies. They are characterized by $\mathrm{Ag}-\mathrm{Hg}$ mineralization exceptionally rich in silver and with high mercury silver contents. From a geological point of view, silver mineralization is associated with rhyolites and granitoids of the same age, terminal Neoproterozoic. Structurally the east-west fractures preferentially mineralized. From the point of view mineralogy, abundance of mercurial 
silver and silver sulphides, geochemically (at least partial similarity of fluids) (Marcoux \& Wadjinny, 2005). The Ore formation conditions are almost the same. The two deposits are considered by several authors (Essarraj et al., 1998 ; Essarraj \&Michard, 2011 ; Levresse, 2001 ; 2004), as epithermal deposits related to the implementation of the terminal Neoproterozoic rhyolite magmatism. The fluids show an early stage of high temperature (near $500^{\circ} \mathrm{C}$ ), suggesting a marked magmatic influence, followed by a rapid decrease, suggesting a subsurface arrival and possible mixing with superficial hypersaline waters. Zgounder and Imiter could be two expressions of the same neoproterozoic epithermal episode, which would extend into the Anti-Atlas, at least on Siroua and Saghro, beginning to define what might well be a metallogenic silver province.

\section{The relationship between the Bou Madine and Imiter deposits}

According to some authors (Abia \& Soulaimani, 2011) the Bou-Madine deposit is a neutral epitermal type. This is also the case for the deposit of Imiter according to Levresse, (2001). The similarities of these deposits are very important, in almost all respects (table 9). The mineralization precipitation occurred towards the end of the acid-to-intermediate eruptive episode of the Tamerzaga-Timrachine "FTT" formation in Bou-Madine. Sub-contemporaneous to the setting of the rhyolitic domes at Imiter dated by at $553 \pm 16 \mathrm{Ma}$, in relation to the mineralization at Imiter. Precipitation of the mineralization would result from mixing with meteoric waters or brine basin Levresse (2001).

\section{The relationship between the Zgounder and Bou Azzer deposits}

Bou Azzer is $45 \mathrm{~km}$ as the crow flies from SW Ouarzazate (Figure 7), in the central Anti-Atlas, Bou Azzer-El Graara buttonhole, located along the major fault Of the Anti-Atlas which constitutes the northern limit of the West African Craton (Wafik et al, 2015). The deposit has been exploited for cobalt since 1933, and silver mining began in 1988. The Bou Azzer-El Graara buttonhole is part of the Pan-African orogenic belt 680-580 Ma. The silver ore is deposited in the quartz diorite connected to an insular arc by (Boudinier et al., 1984). The age of the mineralization is not known, but ther are similarities in the composition of the brine, trapping conditions and the nature of the mineral associations exist between the three deposits-Ag (Bou Azzer, Zgounder, Imiter). These conditions suggest that a major phase of brine circulation and fluid migration produced in the Anti-Atlas (Essarraj et al., 2005). Essarraj (1999), concludes that very similar brines (of the H2O$\mathrm{NaCl}-\mathrm{CaCl} 2$ system) of high salinity have circulated in the Zgounder and Bou Azzer deposits (24-40\% by weight $\mathrm{NaCl}+\mathrm{CaCl} 2$ at $\mathrm{Zgounder}$ and 19 to $45 \%$ wt. $\mathrm{Nacl}+\mathrm{CaCl} 2$ at Bou Azzer), moderate temperature and pressure 
conditions comparable in the two deposits ( $\mathrm{T}$ about $200{ }^{\circ} \mathrm{C}$ and $\mathrm{P}<100$ $\mathrm{MPa})$. These brines gave rise, in the first place, to different parageneses in the two deposits ( $\mathrm{Zn}-\mathrm{Cu}$ to Zgounder and As-Co-Ni to Bou Azzer). They then deposited the economical silver occurence in both deposits, following an evolution marked by a drop in salinity, a slight drop in temperature, and without any significant change in the pressure conditions.

\section{Conclusion}

The main events of the pan-African orogenic cycle in the Anti-Atlasic chain are: the development of a neoproterozoic "Rifted margin" divergence margin, oblique subduction, insular arc formation, continental arc collision and development Of an active continental arc on the northern margin of the COA. The Bou Madine deposit for Levresse (2001) could be of copper porphyry type, but for other authors like Abia \& Soulaimani (2011), it is of epithermal neutral type. The mineralization genesis towards the end of the episode eruptive acid to intermediate formation of Tamerzaga-Timrachine Neoproterozoic terminal. The neutral epithermal type related to the installation of the rhyolitic magmatism at the end of the Neoproterozoic terminal Levresse, $(2001,2004)$ is accepted by the majority of the Authors.

In the Zgounder deposit, the precipitation of silver mineralization and the associated base metals was carried out under epithermal conditions of lower temperature and pressure (Essarraj \& Michard, 2011).

From the synthesis of the work on the main silver deposits of the AntiAtlas (Bou-Madine, Imiter, Zgounder), a number of conclusions can be drawn concerning the relations between these deposits and their relations With the Bou Azzer deposit (Co-Ni-As-Ag-Au).

The Imiter and Zgounder deposit possess strong analogies, they are characterized by $\mathrm{Ag}-\mathrm{Hg}$. They are associated with terminal Neoproterozoic rhyolites, east-west fractures are preferentially mineralized and at least partial similarities of fluids.

Between the deposits of Bou Madine and Imiter, similarities are very important, with essentially mineralization associated with synchronous rhyolite intrusions in the two deposits, dated to $553 \pm 16 \mathrm{Ma}$ and $550 \pm 3 \mathrm{Ma}$ respectively by Levresse (2001 ). Precipitation of the mineralization would result from mixing with meteoric or brine pools in both cases.

The relation is established between the Zgounder and Bou Azzer deposits by Essarraj (1999), this relation consists of: very similar brines of high salinity, which have circulated in both deposits. Under conditions ( $\mathrm{T}$ around $200^{\circ} \mathrm{C}$ and $\left.\mathrm{P}<1 \mathrm{KPa}\right)$.

The silver deposits in the Anti-Atlas are characterized by a number of criteria, which confirm their orogenic character. These deposits are associated with orogenic accretion events in relation to Pan-African 
orogenesis during the Neoproterozoic. The mineralization is syn to post-peak metamorphism, controlled and associated with faults, with veins that may have significant vertical extensions. The gradients of pressure, temperature and metamorphism, indicate an orogenic environment, with metamorphic terranes of greenschist facies. Finally, it can be noted that the silver deposits in the Anti-Atlas are of the orogenic type. They can all be linked to a silver mega-event during the Neoproterozoic and thus define an silver metallogenic province bording west-african craton (figure 10).

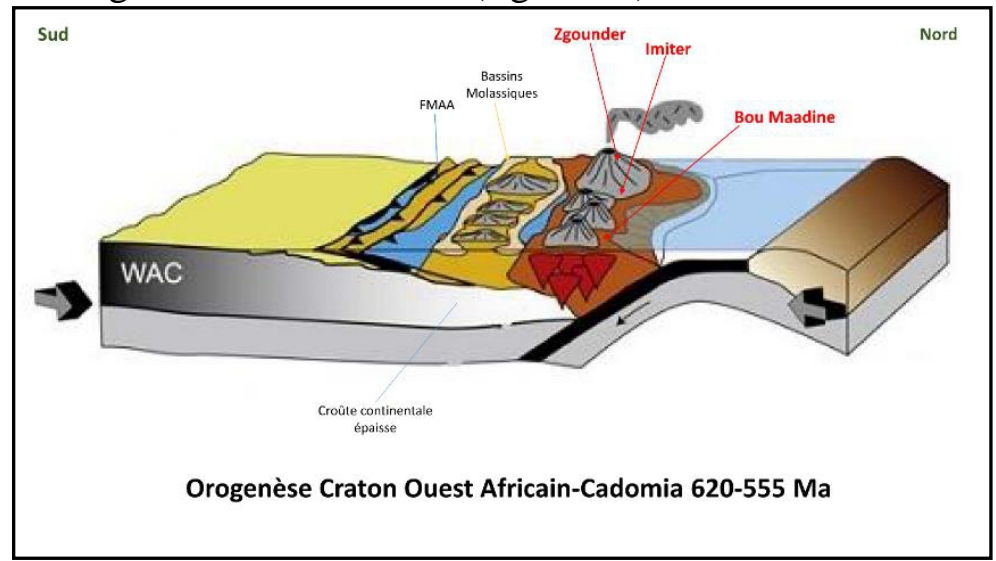

Figure.18. Schematic model of the Proterozoic tectonic evolution of the Anti-Atlas (Saquaque et al. 1989; Hefferan et al. 1992; 2000; Thomas et al. 2002; 2004; Gasquet et al. 2005; 2008; Abati et al. 2010; El Hadi et al. 2010; Walsh et al. ;2012; Hefferan et al, 2014) and Anti-Atlas argentiferous province (this study).

\section{References:}

1. ABATI, J., AGHZER, A.M., GERDES, A., ENNIH, N., (2010): Detrital zircons of Neoproterozoic sequences of the Moroccan AntiAtlas belt. Precambrian Res. 181, 115-128.

2. ABIA E. H., NACHIT H., MARIGNAC C., IBHI A. \& AÏT SAADI S. (2003): The polymetallic Au-Ag-bearing veins of Bou Madine (Jbel Ougnat, eastern Anti-Atlas, Morocco): tectonic control and evolution of a Neoproterozoic epithermal deposit. J. Afr. EarthSci. $36,251-271$.

3. ABIA, E.., Soulaimani, A. (2011): Le gisement polymétallique de Bou-Madine (Ougnat, Anti-Atlas oriental). In Michard et al. (Ed.), nouveaux guides géologiques et miniers du Maroc - volume 9 (pp. 35-40). Maroc : service géologique du Maroc.

4. ABOUCHAMI, W., BOHER, M., MICHARD, A., ALBARÈDE, F., (1990): A major 2.1 Ga old event of mafic magmatism in West Africa: an early stage of crustal accretion. Journal of GeophysicalResearch $95,17605-17629$. 
5. AÏT MALEK, H., GASQUET, D., BERTRAND, J.M., LETERRIER, J., (1998) : Géochronologie U-Pb sur zircon de granitoïdes éburnéens et panafricains dans les boutonnières protérozoïques d'Igherm, du Kerdous et du Bas Drâa (Anti-Atlas occidental, Maroc). Comptes rendus de l'Académie des sciences. Série 2 : Sciences de la terre et des planètes. Paris, France, 327, pp. 819-826.

6. ÁlVARO, J., BELLIDO, F., GASQUET, D., FRANCISCO PEREIRA, M., QUESADA, C., SÁNCHEZ-GARCÍA,T., (2014): Diachronism in the late Neoproterozoic-Cambrian arc-rift transition ofNorth Gondwana: a comparison of Morocco and the Iberian OssaMorena Zone.J. Afr. Earth Sci., in press, http://dx.doi.org/10.1016/j.jafrearsci.2014.03.024.

7. AUVRAY, B., PEUCAT, J.-J., POTREL, A., BURG, J.P., CARUBA, C., DARS, R., LO, K., (1992): Données géochronologiques nouvelles sur l'Archéen de l'Amsaga (Dorsale Réguibat, Mauritanie). Comptes rendus de l'Académie des sciences. Paris, France, 315, 63-70.

8. ARNDT. N.T ET GANINO. C, (2010): Ressources minérales, Origine, nature et exploitation. Dunod, Paris, 2010.

9. AUVRAY, B., PEUCAT, J.-J., POTREL, A., BURG, J.P., CARUBA, C., DARS, R. AND LO, K., (1992) : Données géochronologiques nouvelles sur l'Archéen de l'Amsaga (Dorsale Réguibat, Mauritanie), C.R. Acad. Sci. Paris, 315, pp.63-70.

10. BAIDDER L., RADDI Y., TAHIRI M. \& MICHARD A., (2008): Devonian extension of the Panafrican crust north of the West African Craton, and its bearing on the Variscan foreland deformation: evidence from eastern Anti-Atlas (Morocco), in Ennih N., Liegeois J.P. (Eds.), Geol. Soc. London Spec. Publ. 297, 449-461

11. CHOUBERT, G. (1945): Sur le Précambrien marocain. Comptes Rendus de l'Académie des Sciences de Paris 221 : 249-251.

12. CHOUBERT, G. (1947) : L'accident majeur de l'Anti-Atlas. Comptes Rendus de l'Académie des Sciences de Paris 224 : 1172-1173

13. D'LEMOS, R.S., INGLIS, J.D., SAMSON, S.D., (2006). A newly discovered orogenic event in Morocco: neoproterozoic ages for supposed Eburnean basement of the BouAzzer inlier, Anti-Atlas Mountains. Precambrian Res. 147, 65-78.

14. EL HADI, H., SIMANCAS, J.F., MARTINEZ-POYATOS, D., AZORK, A., TAHIRI, A., MONTERO, P., FANNING, C.M., BEA, F., GONZALEZ-LODEIRO, F., (2010): Structural and geochronological constraints on the evolution of the Bou Azzer Neoproterozoic ophiolite (Anti-Atlas, Morocco). Precambrian Res. $182,1-14$. 
15. ESSARRAJ. S, (1999): Circulations de fluides associées aux minéralisations argentifères de l'Anti-Atlas central ; exemples des gisements de Zgounder (Ag-Hg) et Bou-Azzer (Co-Ni-As-Au-Ag), thèse d'État, université Cadi-Ayyad, Marrakech, Maroc, 358 p.

16. ESSARRAJ. S., BOIRON M.-C., CATHELINEAU M., BANKS D.A. \& BENHARREF M. (2005): Penetration of surface-evaporated brines into the Proterozoic basement and deposition of Co and Ag at Bou Azzer (Morocco): Evidence from fluid inclusions. J. Afr. EarthSci., 41, 25-3

17. ESSARRAJ. S., MICHARD A. (2011): Introduction : Le gîte d'argent de Zgounder (Massif du Siroua). In Michard et al. (Ed.), nouveaux guides géologiques et miniers du Maroc - volume 9 (pp. 81-86). Maroc: service géologique du Maroc.

18. EVANS A.N. (1993): Ore geology and industrial minerals: an introduction, Blackwell Publishing Company, 390 p.

19. FRETON, R., (1988): Contribution à l'étude métallogénique du district de Bou Madine (Anti-Atlas, Maroc) : environnement tectonique et concentrations epithermales BPGC à $\mathrm{Ag}$ et $\mathrm{Au}$. Thèse INPL, Nancy, p.246.

20. JÉBRAK.M \& MARCOUX. É, (2008): Géologie des ressources minérales. Québec : Ressources naturelles et faune.

21. HEFFERAN, K.P., ADMOU, H., KARSON, J.A., SAQUAQUE, A., (2000) : Anti-Atlas (Morocco) role in Neoproterozoic western Gondwana reconstruction. Precambrian Res. 103, 89-96.

22. HEFFERAN, K., ET Soulaimani, A., Samson, S, D., Admou, H., Inglis,J ., Saquaque ,S .,Chaib,L ., Heywood,N. (2014): A reconsideration of Pan African orogenic cycle in the Anti-Atlas Mountains, Morocco. J.A.E. Sci.

23. HELG U., BURKHARD M., CARITG S., ROBERT-CHARRUE CH., (2004): Folding and inversion tectonics in the AntiAtlas of Morocco, Tectonics 23, TC 4006 1-17.

24. HIRDES, W., DAVIS, D.W., EISENLOHR, B.N., (1992): Reassessment of Proterozoic granitoids ages in Ghana on the basis of $\mathrm{U} / \mathrm{Pb}$ zircon and monazite dating. Precambrian Research 56, 8996.

25. GAOUZI, A., L. MAACHA, A. ENNACIRI, A. GMIRA, B. MAAMAR, M. ZOUHAIR \& A. SAQUAQUE, (2011): Mine d'argent d'Imiter (Anti-Atlas oriental, Maroc). In A. Mouttaqi, E.C. Rjimati, Maacha L. , A. Michard, A. Soulaimani \& H. Ibouh (Eds), vol. 9 : Les principales mines du Maroc, Notes et Mém. Serv. Géol. Maroc, $N^{\circ} 564$. 
26. GASQUET D., LEVRESSE G., CHEILLETZ A., AZIZI-SAMIR MR. \& MOUTTAQI A. (2005) : Contribution to a geodynamic reconstruction of the Anti-Atlas (Morocco) during Pan-African times with the emphasis on inversion tectonics and metallogenic activity at the Precambrian-Cambrian transition. Precambr. Res. 140, 157-182.

27. GASQUET, D., ENNIH, N., LIEGEOIS, J.P., SOULAIMANI, A.,

28. MICHARD, A., (2008): The Pan-African belt. In: Michard, A., Saddiqi, O., Chalouan, A., Frizon de Lamotte, D. (Eds.), Continental Evolution: The Geology of Morocco: Lecture Notes in Earth Sciences, 33, pp. 33-64.

29. GUILlOU J.J., MONTHEL J., PICOT P., PILlARD F., J. Et SAMMAMA J.C. (1985). L'imitérite,. Ag2HgS2, nouvelle espèce minérale propriétés et structure cristalline. Bull. Minéral. 108, 457464

30. KERRICH, R., GOLDFARB, R., GROVES, D., AND GARWIN, S., (2000). The geodynamics of world-class 762 gold deposits: characteristics, space-time distributions, and origins. Reviews in 763 Economic Geology, v. 13, p. 501-551.

31. KOUYATÉ, D., SÖDERLUND, U., YOUBI, N., ERNST, R.E., HAFID, A., IKENNE, M., SOULAIMANI, A., BERTRAND, H., EL JANATI, M., RKHA CHAHAM, K., (2013): U-Pbbaddeleyite ages of $2040 \mathrm{Ma}, 1650 \mathrm{Ma}$ and $885 \mathrm{Ma}$ on dolerites in the West African Craton (Anti-Atlas inliers): possible links to break-ups of Precambrian supercontinents.

Lithos. http://dx.doi.org/10.1016/j.lithos.2012.04.028.

32. LEBEDEV V.I., MAACHA L., ZOUHAIR M., EL GHORFI M., BORISENSKO A.S.,. KALININ Yu.A, PAVLOVA G.G., NEVOLKO P.A., AYRIYANTS A.A., BOROVIKOV A.A., GAOUZI A., DERBAL M., BERRADA M.T., ARISTOV V.V., ZADORZHNY D.N., ZELIKSON B.S., ZVEREV S.N., V.I. Titov (2016).Criteria for prediction ofindustrial mineralization inthe imiter ore field(morocco).editor-in-chief academician of the ras v.v. yarmolyuk

33. LEBLANC, M., LANCELOT, J.R., (1980): Interprétation géodynamique du domaine panafricain (Précambrien terminal) de l'Anti-Atlas (Maroc) à partir de données géologiques et géochronologiques. Canadian Journal of Earth Sciences 17, 142-155.

34. LEPRETRE R., (2015) : Evolution phanérozö̈que du Craton Ouest Africain et de ses bordures Nord et Ouest, Thèse Doct., Univ. ParisSud, 422p.

35. LEVRESSE, G., (2001). Contribution à l'établissement d'un modèle génétique des gisements d'Imiter ( $\mathrm{Ag}-\mathrm{Hg})$, Bou Madine (Pb-Zn-Cu- 
Ag-Au) et Bou Azzer (Co-Ni-As-Au-Ag) dans l'Anti-Atlas marocain. Unpubl. Doctorate Thesis, Institut National Polytechnique de Lorraine, Nancy, France, p. 191.

36. LEVRESSE, G., CHEILlETZ, A., GASQUET, D., REISBERG, L., DELOULE, E., MARTY, B., AND KYSER, K., (2004): Osmium, sulphur, and helium isotopic results from the giant Neoproterozoic epithermal Imiter silver deposit, Morocco: evidence for a mantle source: Chemical Geology, v. 207, no. 1-2, p. 59-79.

37. LIEGEOIS J.P., FEKKAK A., BRUGUIER O., ERRAMI E., ENNIH N. (2006): The Lower Ediacaran (630-610 Ma) Saghro group: an orogenic transpressive basin development during the early metacratonic evolution of the Anti-Atlas (Morocco). IGCP485 4th meeting, Algiers, Abstr. Vol. 57.

38. LINDGREN, W.A., (1933): Mineral deposits. McGraw-Hill, New York (4th edition), $930 \mathrm{p}$.

39. MAACHA L. 2013. Place de la boutonnière de BouAzzerdans les SystèmesMétallogéniques de l'Anti Atlas. Apport des DonnéesGéophysiques. ThèsesDoctorat. Universite Caddi Ayyad, Faculté Des Sciences Semlalia- Marrakech

40. MARCOUX E. \& WADJINNY A. (2005) : Le gisement Ag-Hg de Zgounder (Jebel Siroua, Anti-Atlas, Maroc) : une minéralisation épithermale néoprotérozoïque de type Imiter. C. R. Géosciences, 337, 1439-1446.

41. MASSIRONI, M., MORATTI, G., ALGOUTI, A., BENVENUTI, M., DAL PIAZ, G.V., EDDEBBI, A., EL BOUKHARI, A., LAFTHOUHI, N., OUANAIMI, H., SCHIAVO, A., TAJ-EDDINE, K., VISONA, D., (2007): Carte Géologique du Maroc au 1/50,000, feuille Boumalne. Notes andMémoires Service Géologique du Maroc, 521.

42. MITCHELL, A.H.G. AND GARSON, M.S., (1981): Mineral deposits and global tectonic setting. London, Academic Press (Geology Series), $405 \mathrm{p}$.

43. MICHARD A., SADDIQI O., CHALOUAN A. \& FRIZON DE LAMOTTE D. (eds.) (2008). Continental evolution: The geology of Morocco: Structure, stratigraphy, and tectonics of the AfricaAtlantic-Mediterranean triple junction. - Lecture Notes in Earth Sciences, Berlin, vol. 116, 424 p.

44. MICHARD, A., SOULAIMANI, A., HOEPFFNER, C., OUANAIMI, H., BAIDDER, L., RJIMATI E.C., SADDIQI, O., (2010): The South-Western Branch of the Variscan Belt: Evidence from Morocco. Tectonophysics 492, 1-24 
45. MOUTTAQI, A., RJIMATI, E.C, MAACHA, L., MICHARD, A., SOULAIMANI, A. \& IBOUH, H. (2011) : Les principales mines $d u$ Maroc / Main Mines of Morocco. Volume 9 (Notes \&Mém. $\mathrm{n}^{\circ}$ 564)

46. PAILE, Y.,(1983) : Etudes des séries volcaniques de Précambrien III de l'Ougnat (Anti-Atlas oriental, Maroc) et des minérailisations plombo-zincifères complexes associées (gîte de Bou Madine). Thèse 3ème cycle, Paris XI Orsay, p.290.

47. PASAVA, J. (1994): Geochemistry and the role of anoxic sediments in the origin of the Imiter silver deposit in Morocco. Vestník Ceskéhogeologick éhoustavu 69 (1): 1-11

48. PEUCAT, J.-J., CAPDEVILA, R., DRARENI, A., MAHDJOUB, Y. AND KAHOUI, M., (2005): The Eglab massif in the West African Craton (Algeria), an original segment of the Eburnean orogenic belt: petrology, geochemistry and geochronology, Precamb. Res., 136, pp.309-352.

49. POTREL, A., PEUCAT, J.-J., FANNING, C.M., AUVRAY, B., BURG, J.P. AND CARUBA, C., (1996): 3.5 Ga old terranes in the West African Craton, Mauritania, J. Geol. Soc., London, 153, pp.507-510.

50. POTREL, A., PEUCAT, J.-J. AND FANNING, C.M., (1998). Archean crustal evolution of the West African Craton: example of the Amsaga Area (Reguibat Rise). U-Pb and Sm-Nd evidence for crustal growth and recycling, Precamb. Res., 90, pp.107-117.

51. ROCCI, G., BRONNER, G. AND DESCHAMPS, M., (1991): Crystalline basement of the West African craton, In: Dallmeyer, R.D. and Lécorché, J.-P., The West African orogens and Circum-Atlantic Correlatives, pp.31-61, Springer-Verlag, Berlin Heidelberg.

52. SAMSON, S.D., INGLIS, J.D., D'LEMOS, R.S., ADMOU, H., BLICHERT-TOFT, J., HEFFERAN, K., (2004): Geochronological, geochemical, and $\mathrm{Nd}-\mathrm{Hf}$ isotopic constraints on the origin of Neoproterozoic plagiogranites in the Tasriwine ophiolite, Anti-Atlas orogen, Morocco. Precambrian Research 135, 133-147.

53. SAQUAQUE, A., ADMOU, H., KARSON, J., HEFFERAN, K., REUBER, I., (1989): Precambrian accretionary tectonics in the BouAzzer-El-Graara region, Anti-Atlas, Morocco. Geology 17, 11071110 .

54. SCHIAVO, A., TAJ-EDDINE, K., ALGOUTI, A., BENVENUTI, M., DAL PIAZ, G.V., EDDEBBI,A., EL BOUKHARI, A., LAFTOUHI, N., MASSIRONI, M., MORATTI, G., OUANAIMI, H.,PASQUARÉ, G., VISONA, D., (2007): Carte Géologique $d u$ Maroc au 1/50,000, feuille Imiter. Notes et Mémoires du Service Géologique du Maroc,518. 
55. SOULAIMANI, A. (2006) : Introduction : Le Maroc, Afrique saharienne, atlantique et méditerranéenne. In PIQUE, A.SOULAIMANI, A. AMRHAR, M. LAVILLE, E. BOUABDELLI, M. HOEPFFNER, C. CHALOUAN, A. (Ed.), Géologie du maroc, pp. 01-36. Maroc : Maison d'édition inconnue.

56. TUDURI J., (2005): Processus de formation et relations spatiotemporelles des minéralisations à or et argent en contexte volcanique Précambrien (Jbel Saghro, Anti-Atlas, Maroc). Implications sur les relations déformation-magmatisme volcanisme-hydrothermalisme., These Doct., Univ. D’Orléans, 466p.

57. TUDURI J., CHAUVET A., ENNACIRI A., BARBANSON L. (2005) : Modèle de formation du gisement d'argent d'Imiter (AntiAtlas oriental, Maroc). Nouveaux apports de l'analyse structurale et minéralogique. C. R. Géoscience, 338, pp. 253-261.

58. THOMAS, R.J., CHEVALLIER, L.P., GRESSE, P.G., HARMER, R.E., EGLINGTON, B.M., ARMSTRONG, R.A., DEBEER, C.H., MARTINI, J.E.J., DEKOCK, G.S., MACEY, P.H., INGRAM, B.A., (2002) : Precambrian evolution of the Sirwa Window, Anti-Atlas Orogen, Morocco. Precambrian Research 118, 1-57.

59. THOMAS, R.J., FEKKAK, A., ENNIH, N., ERRAMI, E., LOUGHLIN, S.C., GRESSE, P.G., CHEVALLIER, L.P., LIÉGEOIS, J.P., (2004): A new lithostratigraphic framework for the Anti-Atlas Orogen, Morocco. J. Afr. Earth Sci. 39, 217-226.

60. WAFIK, A., BHILISSE, M., ADMOU, H., MAACHA, L., ELGHORFI, M., CONSTANTIN, M., (2015) : the podiform chromite and platinum partners in the neoproterozoic ophiolite Bou Azzer (inlier Bou Azzer - El Graara, central Anti-Atlas). European Scientific Journal, edition vol.11, No.36, pp.122-140.

61. WALSH, G.J., BENZIANE, J.N., ALEINIKOFF, F., HARRISON, R.W., YAZIDI, A., BURTON, W.C., QUICK, J.E., SAADANE, A., (2012): Neoproterozoic tectonic evolution of the Jebel Saghro and Bou Azzer-El Graara inliers, eastern and central Anti-Atlas, Morocco. Precambrian Res. 216, 23-62.

62. D'LEMOS, R.S., INGLIS, J.D., SAMSON, S.D., (2006): A newly discovered orogenic event in Morocco: neoproterozoic ages for supposed Eburnean basement of the Bou Azzer inlier, Anti-Atlas Mountains. PrecambrianRes. 147, 65-78.

63. http://dx.doi.org/10.1016/j.jafrearsci.2014.03.007 